\title{
Effects of Extracellular Matrix Proteins on the Growth and Differentiation of an Anaplastic Glioma Cell Line
}

\author{
James T. Rutka
}

\begin{abstract}
Efforts to determine the factors responsible for reversing malignancy in the central nervous system may not only increase our understanding of the growth of primary human brain tumors, but may eventually prove to be of therapeutic benefit as well. We therefore devised a model system to study the effects of extracellular matrix (ECM) proteins on the malignant phenotype of an anaplastic glioma line, U-343 MG-A. Well-characterized cultures derived from normal human leptomeninges were grown to confluence and maintained for 2 weeks. The pia-arachnoid cells were then removed with detergent and base, leaving behind an ECM enriched in laminin, fibronectin, types I and IV collagen, and procollagen III. U-343 MG-A tumor cells planted on top of this normal ECM were profoundly growth inhibited, developed multiple slender cytoplastic processes similar to those of normal astrocytes, and expressed more GFAP per cell than did tumor cells growing on plastic alone. The growth of U-343 MG-A tumor cells in flasks coated with purified fibronectin or laminin was not significantly inhibited. However, U-343 MG-A cultures grown in flasks coated with type I or IV collagen showed decreased cellular proliferation and altered cell morphology. Conditioned medium from U-343 MG-A tumor cells growing on plastic alone contained a $64 \mathrm{kD}$ activated metalloprotease. U-343 MG-A tumor cells growing on the pia-arachnoid ECM do not demonstrate such proteolytic activity. We conclude that the tumor cell microenvironment is extremely important in modulating the growth and differentiation of an anaplastic glioma cell line. It is hoped that an increased knowledge of the production of ECM components and their effects on malignant glioma cell growth, migration and differentiation will lead to the development of new approaches to improve the prospects of patients with primary malignant brain tumors.
\end{abstract}

RÉSUMÉ: Les effort entrepris pour déterminer les facteurs responsables de la régression des tumeurs malignes du système nerveux central peuvent non seulement accroître notre compréhension de la croissance des tumeurs cérébrales primitives chez l'humain, mais aussi s'avérer utiles éventuellement au point de vue thérapeutique. Nous avons donc développé un système modèle pour étudier les effets des protéines de la matrice extracellulaire (MEC) sur le phénotype de malignité d'une lignée de gliome anaplasique, U-343 MG-A. Nous avons cultivé jusqu'à confluence des cultures bien caractérisées, développées à partir de leptoméninges humaines normales et nous les avons maintenues pendant deux semaines. Les cellules provenant de l'arachnoïde et de la pie-mère furent alors éliminées au moyen de détergent et d'une solution basique, ne laissant qu'une MEC riche en laminine, en fibronectine, en collagène de type I et IV et en procollagène III. Les cellules tumorales U-343 MG-A ensemencées par-dessus cette MEC normale ont présenté une croissance très inhibée. Elles ont développé de multiples prolongements cytoplasmiques ténus, semblables à ceux d'astrocytes normaux et ont émis plus de PGFA par cellule que les cellules tumorales croissant seulement sur le plastique. La croissance des cellules tumorales U-343 MG-A dans des flacons enduits de fibronectine ou de laminine purifiée n'était pas inhibée de façon significative. Cependant, les cultures U-343 MG-A ensemencées dans des flacons enduits de collagène de type I ou IV présentaient une prolifération cellulaire moindre et une morphologie cellulaire modifiée. Le milieu de culture conditionné provenant de cellules tumorales cultivées sur le plastique contenait une métalloprotéase activée de type $64 \mathrm{kD}$. Les cellules tumorales U-343 MG-A croissant sur la MEC provenant de l'arachnoïde de la pie-mère n'ont pas manifesté une telle activité protéolytique. Nous concluons que le micro-environnement de la cellule tumorale est extrêmement important pour la modulation de la croissance et de la différenciation d'une lignée cellulaire anaplasique provenant d'un gliome. Nous espérons qu'une meilleure connaissance de la production des composantes de la MEC et de leurs effets sur la croissance des cellules malignes du gliome, sur leur migration et sur leur différenciation, mènera au développement de nouvelles approches dans le but d'améliorer les perspectives d'avenir des patients atteints de tumeurs malignes primitives du cerveau.

Can. J. Neurol. Sci. 1986: 13:30I-306

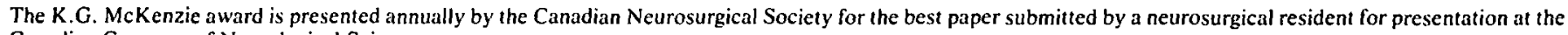
Canadian Congress of Neurological Sciences

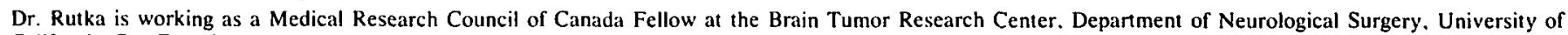
California, San Francisco

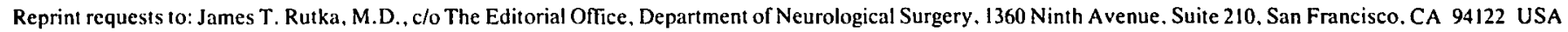


As the limits of surgery, radiation therapy, and conventional chemotherapy are being reached in the management of patients with primary malignant brain tumors, it is clear that in order to develop alternative approaches to treatment, we need to increase our understanding of tumor cell biology and the malignant astrocytic phenotype. Cancer is thought to develop in a stepwise fashion beginning with the process of initiation (Figure 1).
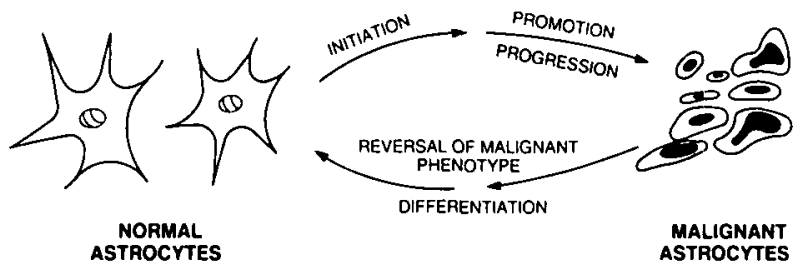

Figure I - Multi-step theory of carcinogenesis as applied to human astrocytic tumors. Recent evidence suggests that tumor cells can be forced to differentiate along a pathway leading towards a more normal cell phenonpe.

Initiation requires a heritable change in cellular DNA that occurs through exposure to agents such as ultraviolet light, $X$-rays, and certain organic and inorganic carcinogens. This process is followed by a promotion stage in which previously initiated cells undergo malignant transformation. The classic tumor promoters include the organic compounds known as the phorbol esters. ${ }^{2}$ Finally, the cells pass through a progression stage until a cancer is formed.

It was thought until very recently that the cancer cell phenotype was irreversible. However, it is becoming apparent that a variety of cancer cells can be "tricked" into following a differentiation pathway toward a more normal phenotype. ${ }^{3-7}$ Such differentiation agents include the retinoids, dimethysulfoxide, and $\mathrm{N}$-methyl formamide. In our study, we have been able to show for the first time that malignant astrocytes can be forced to differentiate toward normal by exposure to proteins of the extracellular matrix (ECM).

\section{Table 1: Primary Components of the ECM}

Collagens

Noncollagenous glycoproteins (laminin, fibronectin)

Glycosaminoglycans (GAGs)

Proteoglycans

The ECM can be defined biochemically as the sum of its component parts (Table 1). ${ }^{8.9}$ These parts include the collagen types (types $\mathrm{I}-\mathrm{V}$, depending on the organ system); the noncollagenous glycoproteins, such as fibronectin and laminin; the glycosaminoglycans (GAGs), such as hyaluronic acid and heparin sulfate; and the proteoglycans. The ECM can also be defined biologically as the naturally occurring extracellular adhesive or "cement" that promotes cell adhesion and expression of the normal cell phenotype.

In most organ systems, the structure of the ECM can be represented in diagrammatic form as a series of extracellular proteins that have fairly specific spatial relationships with each other and with the cells to which they bind (Figure 2). Type IV collagen usually forms a scaffolding to which linking proteins such as laminin and fibronectin bind cells. ${ }^{9-12}$ Proteoglycans

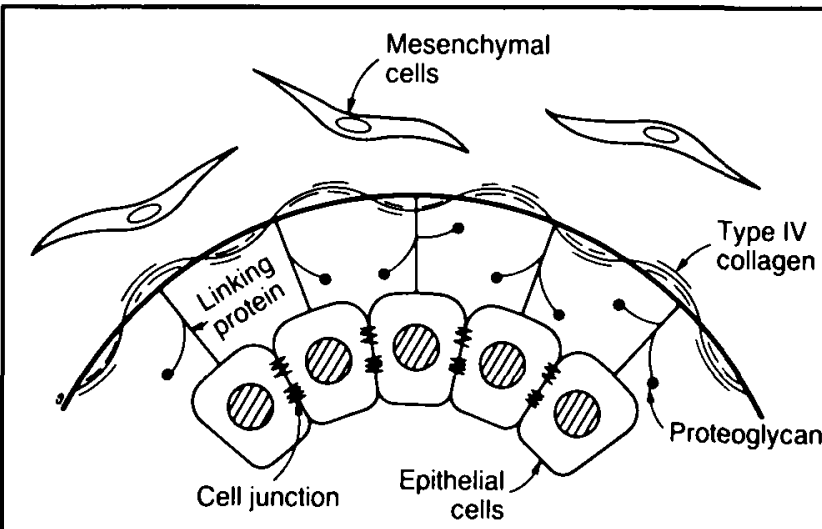

\section{LUMEN}

Figure 2 - Current paradigm for depicting the structure of the extracellular matrix as a basement membrane in most epithelial cell systems outside the central nervous system. Type IV collagen forms a scaffolding to which linking proteins such as laminin and fibronectin bind cells. Heparin sulfate proteoglycan is also embedded in the meshwork of basement membrane proteins.

such as heparin sulfate proteoglycan are also intimately involved in the architecture of the ECM. While this depiction serves as a valuable paradigm for the ECM in most epithelial cell systems, the ECM of the central nervous system (CNS) is different in some respects.

Although the nature of many of the proteins that constitute the extracellular spaces between intrinsic neuronal and glial elements in the CNS has yet to be fully delineated, a true ECM exists in the CNS in the form of a basement membrane between astrocytic foot processes and pia-arachnoid cells at the glial limitans externa, and between these processes and endothelial cells at the capillary basement membrane (Figure 3 ). ${ }^{13}$ These two basement membranes have been well characterized and, as in other tissue systems, contain types I, III, and IV collagen,

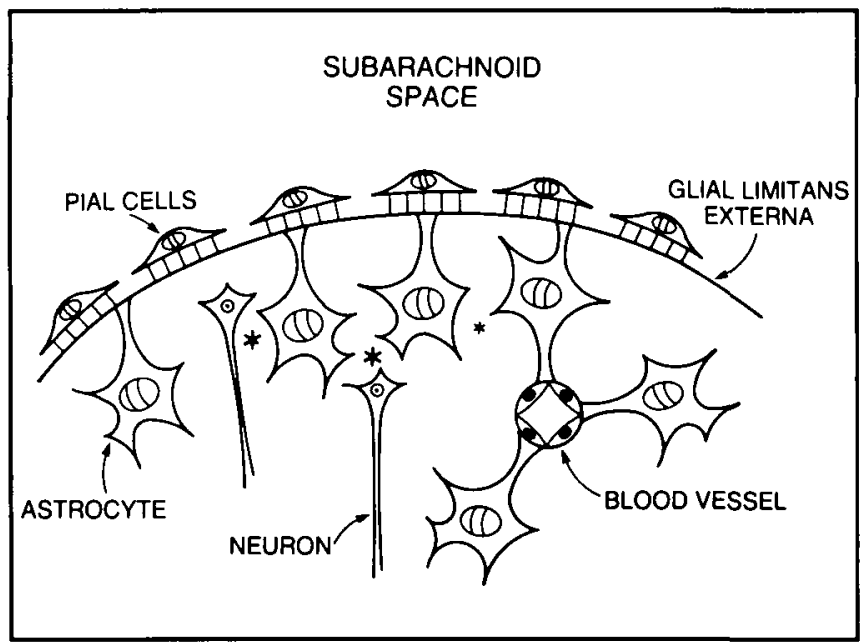

Figure 3 - Model of the extracellular matrix in the central nervous system. True basement membranes exist at the glial limitans externa and at the capillary basement membrane. Basement membranes are deposited at points where astrocyic foot processes meet pia-arachnoid or mesenchymal elements. The extracellular matrix proteins that occur between intrinsic neuronal and glial elements (asterisks) have yet to be completely characterized. 
fibronectin, laminin, and heparin sulfate proteoglycan. ${ }^{14-16} \mathrm{We}$ have previously shown that pia-arachnoid cells in culture synthesize generous quantities of ECM proteins, ${ }^{17}$ and we have taken advantage of this finding in the experiments described below.

We used well-characterized normal pia-arachnoid cells in culture and a malignant glioma cell line, U-343 MG-A, to test the effects of pia-arachnoid ECM proteins on the malignant glioma cell phenotype. Pia-arachnoid cells in culture synthesize and secrete laminin, fibronectin, hyaluronic acid, and types I, III, and IV collagen. ${ }^{17}$ Malignant glioma cell line U-343 MG-A was chosen because it has an infinite lifespan, attains a high terminal cell density, and carries the astrocyte-specific marker glial fibrillary acidic protein (GFAP) over serial passages. ${ }^{18}$

The design of our experiment was conceptually simple. We grew pia-arachnoid cells in culture for about 2 weeks until they formed a confluent monolayer and had synthesized a dense meshwork of ECM proteins (Figure 4). The cells were then incubated in a solution of Triton X-100 (0.1\% for 30 minutes) and then in ammonium hydroxide ( $25 \mathrm{mM}$ for 3 minutes), which removed the cells but left the normal ECM proteins behind. U-343 MG-A tumor cells were then seeded on top of the

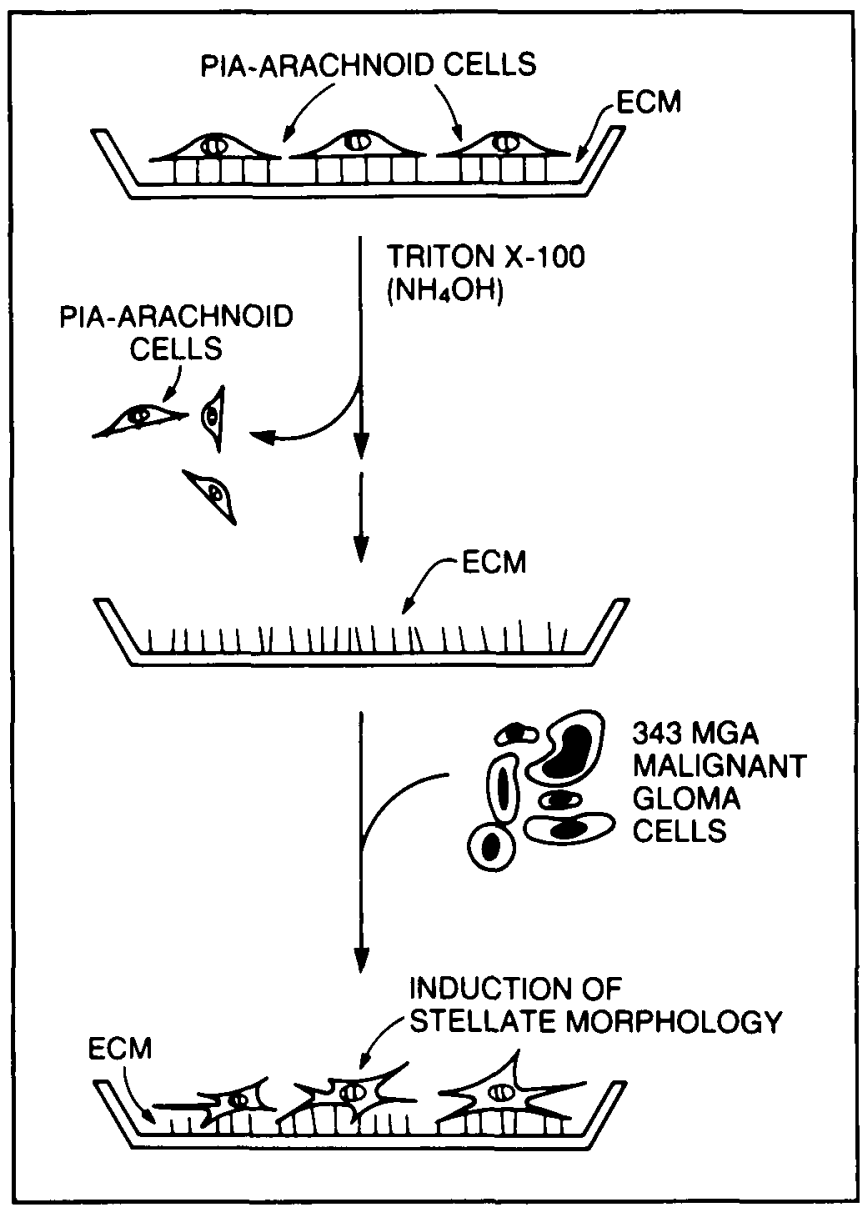

Figure 4-Experimental design. Pia-arachnoid cellswere grownunder standard culture conditions for 2 weeks beyond confluence. The pia-arachnoid cells were then removed by treatment with Triton X.100 and ammonium hydroxide, leaving behind the normal extracellular matrix (ECM). Malignant glioma cells were then seeded on top of the pre-formed ECM and growth was compared with that of tumor cells growing on plastic alone. Stellate morphology was induced in glioma cells grown on the ECM. normal pia-arachnoid ECM. To our surprise, U-343 MG-A tumor cells treated in this fashion were profoundly growth inhibited and began to resemble normal astrocytes insofar as they began to sprout multiple, slender, cytoplasmic processes (Figure 5).

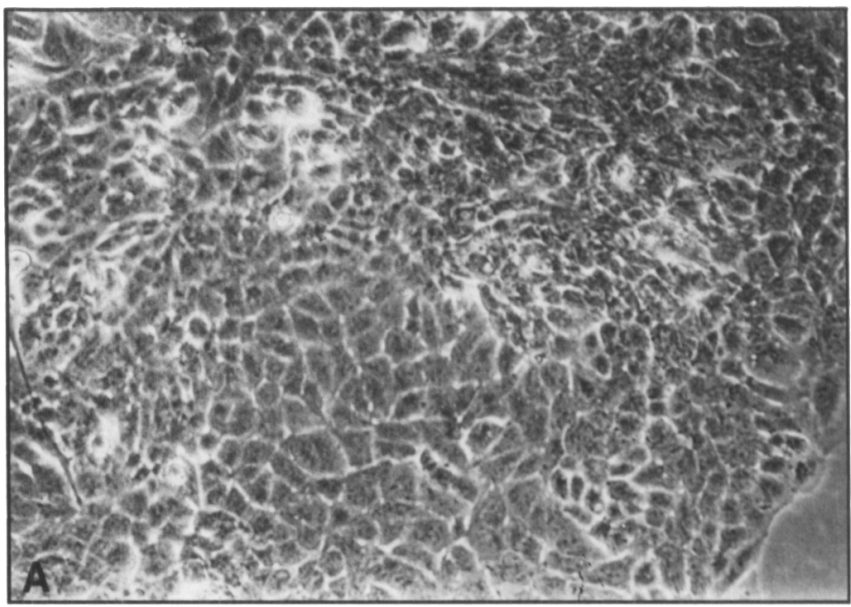

Figure 5 - (A) U-343 MG-A tumor cells grown on plastic alone are cuboidal and show signs of crowding and piling. Phase microscops, $X 250$.

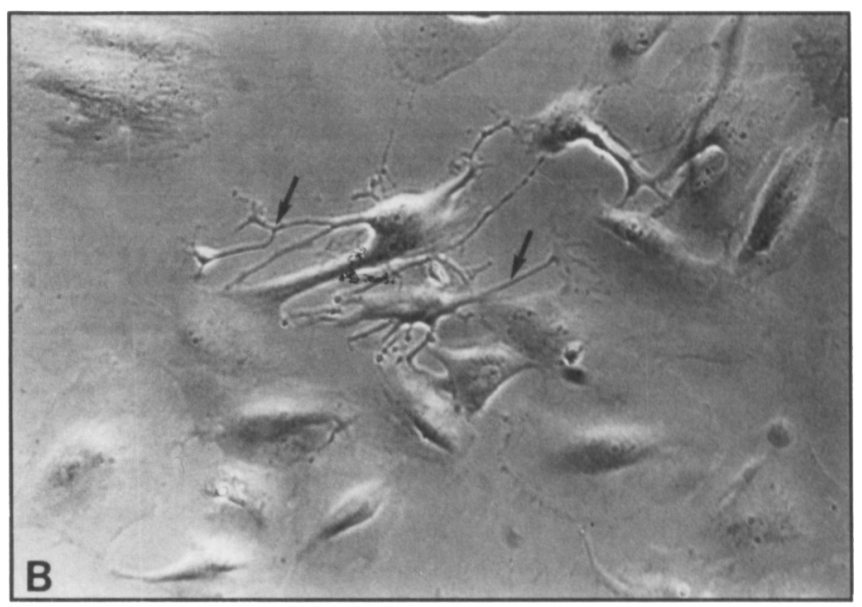

Figure $5-(B)$ U-343 MG-A tumor cells grow'n on an extracellular matrix from normal pia-arachnoid cells. There is no colony formation and the cells have an increased cvoplasmic:muclear ratio; many of the cells have multiple, thin, cytoplasmic processes and resemble normal astrocytes in culture. Phase microscopy, X 350.

To determine the effects of normal pia-arachnoid ECM proteins on the proliferation of U-343 MG-A tumor cells, growth curves were generated for tumor cells grown on plastic alone and for those grown on a layer of pia-arachnoid ECM proteins (Figure 6). At 10 days, U-343 MG-A cultures grown on the ECM exhibited 100-fold fewer cells than cultures grown on plastic alone. This nearly $2-\log$ difference in cell number, in the absence of cytotoxicity, strongly suggests the suppression of the malignant phenotype.

After demonstrating that both the morphology and proliferation of malignant glioma cells were influenced by ECM proteins, we sought to test whether these tumor cells were, in fact, following a pathway of increased differentiation. The measurement of differentiation in most in vitro systems demands reliable markers that signify the presence of a more differentiated 


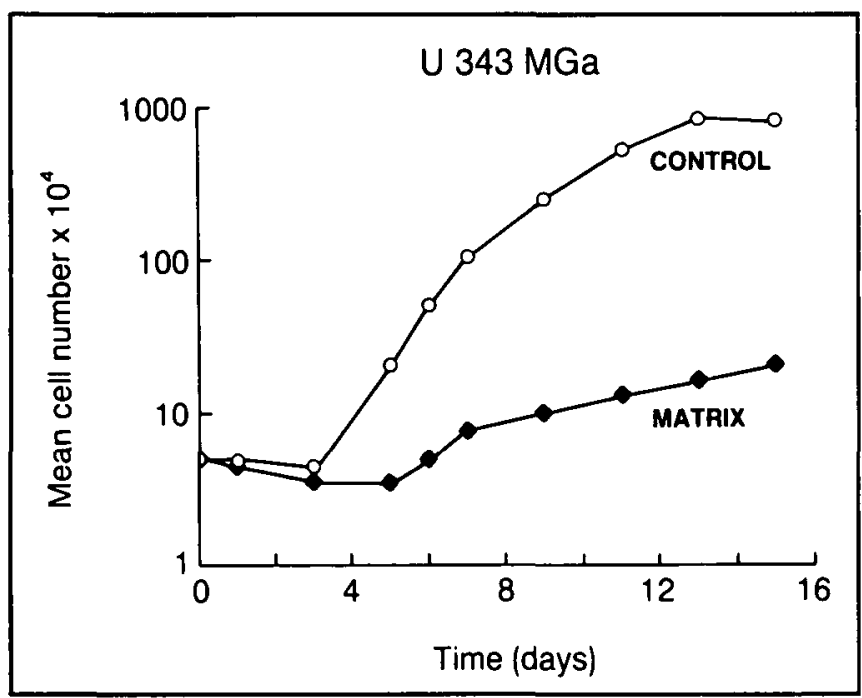

Figure 6-Growth curves for U-343 MG.A tumor cells grown on plastic alone (circles) or on the pia-arachnoid extracellular matrix (diamonds). At day 15, the malignant glioma cells grown on the extracellular matrix were markedly growth inhibited compared with tumor cells grown on plastic. The difference in cell numbers between the two curves is almost 2 log. Vertical axis represents the number of cells per $25 \mathrm{sq} \mathrm{cm}$ flask.

phenotype. ${ }^{19}$ Markers of differentiation in other systems include the measurement of melanin synthesis and tyrosinase activity in malignant melanoma, ${ }^{20.21}$ the levels of serine protease plasminogen activator in teratocarcinoma, ${ }^{22}$ and the reduction of nitroblue tetrazolium in promyelocytic leukemia. ${ }^{23}$

For glial neoplasms, the presence and relative amount of GFAP have been used as a marker of differentiation because GFAP levels are thought to be increased in normal and welldifferentiated astrocytes and decreased in malignant and poorly differentiated astrocytes. A technique has recently been developed that permits the measurement of nanogram quantities of GFAP in tissue sections and cultures based on an enzymelinked immunosorbent assay (ELISA). ${ }^{24}$ In this assay, a color reaction product is generated in proportion to the amount of GFAP in the sample. Using this technique, we found that U-343 MG-A tumor cells growing on a pia-arachnoid ECM had approximately 20 times more GFAP per cell then did U-343 MG-A tumor cells growing on plastic alone. This finding strongly suggested that growing malignant glioma cells on ECM molecules induced differentiation.

Once we knew that the ECM inhibited the growth of U-343 MG-A tumor cells, we sought to determine which component or components of the ECM were responsible for this effect by performing a series of growth-curve experiments in which the malignant glioma cells were cultured in flasks previously coated with single proteins of the ECM (Figure 7). Type I and type IV collagen each inhibited U-343 MG-A tumor cell proliferation to a moderate degree, although not to the extent that the entire pia-arachnoid ECM did; but neither laminin nor fibronectin had any effect on tumor cell growth. Work in progress will determine what combinations of ECM components cause the profound growth inhibition seen with tumor cells grown on a complex ECM. Such information will be important in determining how ECM proteins interact, presumably with the tumor cell plasma membrane, to inhibit cell growth. ${ }^{25}$

We conclude from the results of these experiments that malignant glioma cells growing on a pia-arachnoid ECM exhibit the

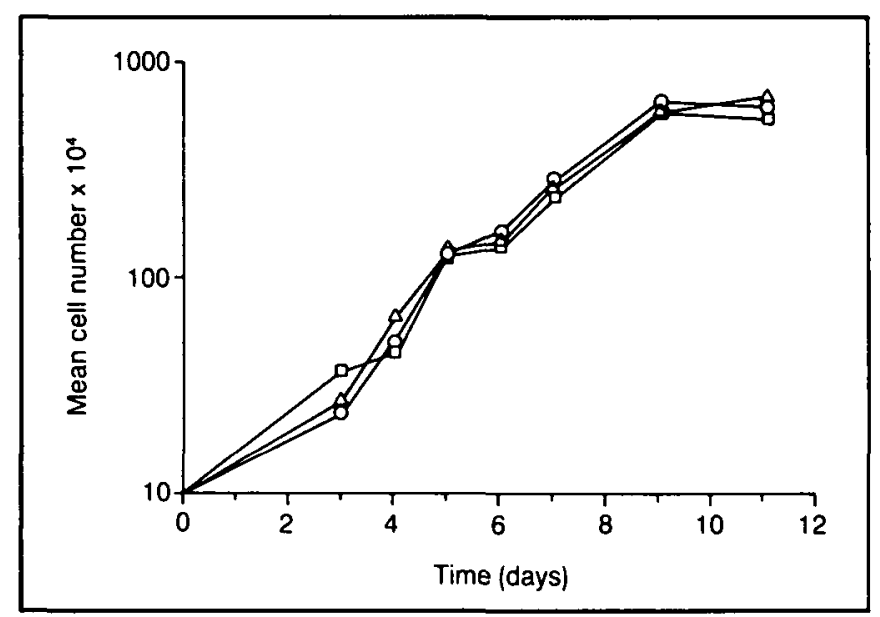

A

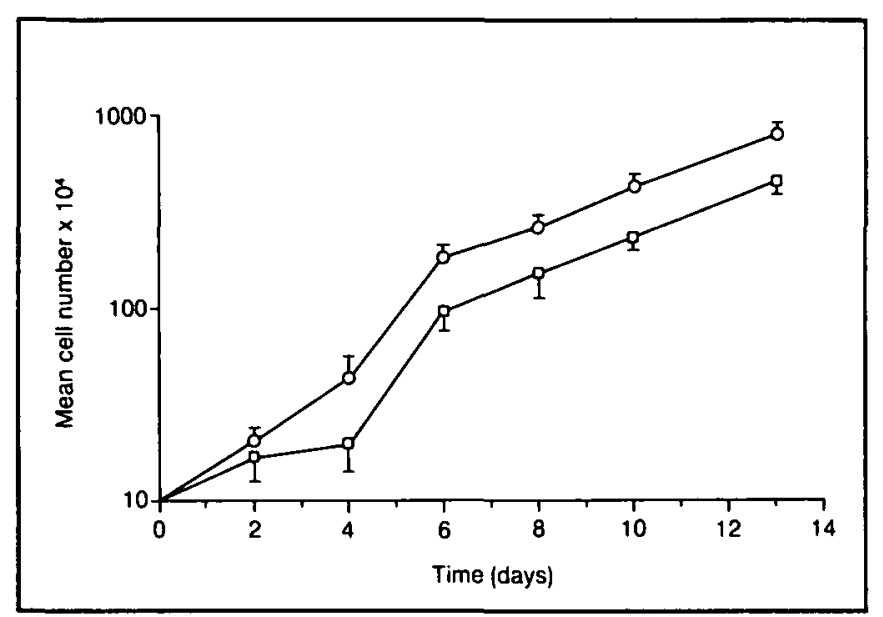

B

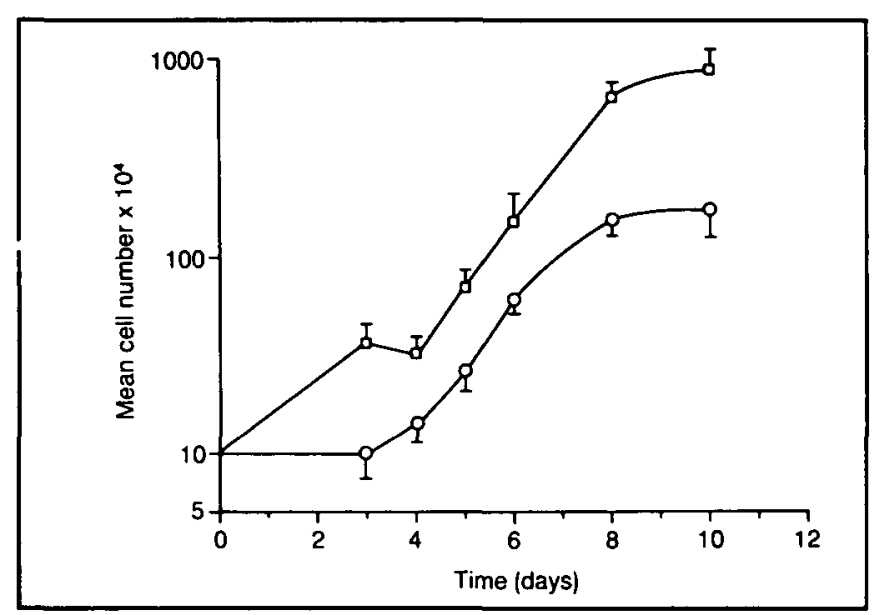

$\mathrm{C}$

Figure 7 - Growth curves for U-343 MG-A tumor cells grown on single components of the extracellular matrix. Vertical axis represents the number of cells per $25 \mathrm{sq} \mathrm{cm}$ flask. (A) The growth of the malignant glioma cells on a coat of either fibronectin (squares) or laminin (circles) is unchanged compared with the growth of the tumor cells on plastic alone (triangles). (B) Malignamt glioma cells grown on a matrix of type IV collagen (squares) show a small degree of growth inhibition compared with control cultures grown on plastic alone (circles). (C) Glioma cells seeded onto a coating of type I collagen (circles) showed a moderate degree of growth inhibition compared with control (squares). The growthinhibitory effects of the collagen types are not as pronounced as those of the entire extracellular matrix (Figure 6). 
Table 2: The effects of different substrata on the growth and differentiation of U-343 MG-A malignant glioma cells

\begin{tabular}{|c|c|c|c|c|c|c|}
\hline & \multicolumn{6}{|c|}{ Substratum } \\
\hline & Plastic & $\mathbf{E C M}$ & Fibronectin & Laminin & Collagen I & Collagen IV \\
\hline \multicolumn{7}{|l|}{ Stellate } \\
\hline Morphology & - & $+t+$ & - & 一 & $+t$ & + \\
\hline \multicolumn{7}{|l|}{ Growth } \\
\hline Inhibition & - & $+t+$ & - & - & ++ & + \\
\hline \multicolumn{7}{|l|}{ GFAP (pg/cell } \\
\hline$\times\left(0^{-2}\right)$ & 3 & 60 & 5 & 4 & 20 & 18 \\
\hline
\end{tabular}

$\mathrm{ECM}=$ extracellular matrix $; \mathrm{GFAP}=$ glial fibrillary acidic protein $;-=$ no effect $+=$ minimal effect $+++=$ moderate effect $;+++=$ maximum effect.

greatest increase in stellate morphology, growth inhibition, and GFAP expression (Table 2). The tumor cells do not appear to be influenced at all by growth on laminin- or fibronectin-coated flasks. Growth on type I or type IV collagen substratum alters tumor cell growth and differentiation to an intermediate degree.

The next question we asked was, what does the ECM do to these malignant glioma cells that prevents them from dividing and encourages them to differentiate? To answer this, we turned to an analysis of tumor-associated protease production. Proteases can be characterized in part by their active moieties, the conditions needed for their activation, and by the types of inhibitors that prevent their action. Several known proteases are listed in Table $3 .{ }^{30}$ Tumor invasiveness is thought to occur

\begin{tabular}{llll}
\hline Table 3: Protease Classification* & & \\
\hline \hline Type of Protease & Active Moiety & Examples & Inhibitors \\
\hline Serine & hydroxyl & trypsin, elasin & DFP, PMSF \\
Metallo & metal group & collagenase & EDTA \\
Cysteine & thiol & papain & NEM \\
Aspartic & aspartatyl & pepsin & pepstatin \\
\hline
\end{tabular}

*After Barrett AJ: The classification of proteinases. In: Evered D, Whelan I, eds. Protein Degradation in Health and Disease (Ciba Foundation Symposium 75). Amsterdam: Excerpta Medica, 1980, pp 1-13.

in part because the tumor cells secrete a variety of these substances, which act to degrade large ECM proteins, including basement membranes. ${ }^{26-29}$ The dissolution of basement membranes facilitates the migration, penetration, and hematogenous dissemination of tumor cells. To determine if ECM proteins have any effect on protease production by malignant glioma cells, we collected serum-free conditioned medium from U-343 MG-A tumor cells growing on plastic alone and medium from those growing on the pia-arachnoid ECM and analyzed these media for protease activity.

Tritiated-elastin and Azocoll assays showed no significant levels of general proteolytic activity in the malignant glioma cell conditioned medium. However, SDS-polyacrylamide gels copolymerized with gelatin and incubated at pH 8.0 (Figure 8) demonstrated a major proteolytic species of $65 \mathrm{kD}$ in the conditioned medium of tumor cells growing on plastic alone. Incuba-

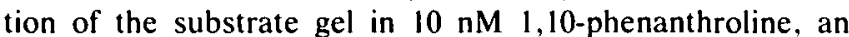
inhibitor of metalloproteinases, inhibited the proteolytic activity. Therefore, U-343 MG-A tumor cells appear to secrete a metalloproteinase, which we are in the process of characterizing more fully. Our preliminary data suggest that conditioned

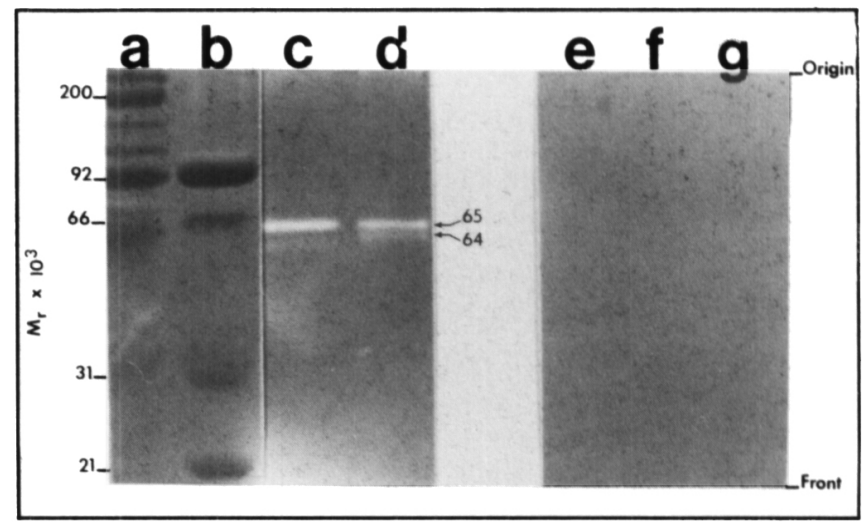

Figure 8-Gelatingel(TRIS bufferpH 8.0) demonstrating a majorproteolytic species at $65 \mathrm{kD}$ (lane c) from the conditioned medium of $U-343 \mathrm{MG} \cdot A$ glioma cells grown on plastic alone. Incubation of the sample with $/ \mathrm{mM}$ 4-aminophenylmercuric acetate (APMA, Sigma), a protease activator, resulted in an "activated" enzyme with a nolecular weight of about $64 \mathrm{kD}$ (lane d). Conditioned medium from U-343 MG-A glioma cells grown on the extracellular matrix did not contain any proteolytic species (lane e). Incubation of the substrate gel in $10 \mathrm{mM}$ l.10-phenanthroline. an inhibitor of metalloproteinases, resulted in complete inhibition of the proteolytic activity (lanes $f$ and $g$ ). Molecular weight standards (lanes $a$ and $b$ ) are phosporylase b $(92,500)$, bovine serum albumin $(66.200)$ carbonic anhivdrase $(31,000)$, and soy-bean trypsin inhibitor $(21.500)$.

medium from U-343 MG-A tumor cells growing on a pia-arachnoid ECM do not secrete such a metalloproteinase. The ECM in this system, therefore, may act to decrease protease production and prevent tumor cell migration. The mechanism by which protease production is inhibited by the ECM remains to be determined.

In summary, in our model system, the ECM produced by normal pia-arachnoid cells in culture profoundly affected the morphology of, inhibited the growth of, and induced differentiation in a malignant glioma cell line. To our knowledge, this is the first study that demonstrates the suppression of the malignant phenotype by ECM macromolecules in the CNS. The growth-inhibiting and differentiating effects of the ECM appear to be mediated in part by types I and IV collagen. Malignant glioma cells exposed to ECM proteins appear to secrete fewer proteases than do malignant glioma cells grown on plastic alone. It is clear from our experiments that the tumor cell microenvironment is extremely important in modulating the growth of a malignant glioma cell line. We hope that increased knowledge concerning the production of ECM components and their influences on malignant glioma cell growth, migration and differentiation, will lead to the development of better treatment for patients with primary malignant brain tumors. 


\section{ACKNOWLEDGEMENT}

I thank Jane Giblin and Gerry Apodaca for their expert technical assistance, Cynthia Robinson for typing the manuscript, and Stephen Ordway for editorial assistance. This work was supported in part by a grant from the Preuss Foundation.

\section{REFERENCES}

I. Miller EC, Miller JA. Searches for ultimate chemical carcinogens and their reactions with cellular macromolecules. Cancer 1981; 47: $2327-2345$.

2. Hecker E. Structure-activity relationships in diterpene esters irritant and cocarcinogenic to mouse skin. In: Slaga TJ, Sivak A, and Boutwell RK, eds. Carcinogenesis. A comprehensive survey, Mechanisms of Tumor Promotion and Cocarcinogenesis, New York: Raven Press, 1978: 11-48.

3. Breitman TR, Selonick SE, Collins SJ. Induction of differentiation of the human promyelocytic leukemia cell line (HL-60) by retinoic acid. PNAS 1980; 77: 2936-2940.

4. Davies PJA, Moore WT Jr, Murtaugh MP. Retinoid-regulated gene expression in normal and leukemic myeloid cells. Bio-Essays 1985: 1: 160-165.

5. Dion LD, Blalock JE, Gifford GE. Retinoic acid and the restoration of anchorage dependent growth to transformed mammalian cells. Exp Cell Res 1978; 117: 15-22.

6. Sporn MB, Roberts AB. Role of retinoids in differentiation and carcinogenesis. Cancer Res 1983; 43: 3034-3040.

7. Sidell N. Retinoic acid-induced growth inhibition and morphologic differentiation of human neuroblastoma cells in vitro. JNCI 1982; 68: 589-593.

8. Hay ED. Extracellular matrix. J Cell Biol 1981; 91: 205s-223s.

9. Reid LM, Fefferson DM. Cell culture studies using extracts of ECM to study growth and differentiation in mammalian cells. In: Mather JP, ed. Mammalian Cell Culture. New York: Plenum, $1984 ; 239-280$

10. Laurie GW, LeBlond CP, Martin GR. Localization of type IV collagen, laminin, heparin sulfate proteoglycan, and fibronectin to the basal lamina of basement membranes. J Cell Biol 1982;95: 340-344.

11. Timpl R, Rhode H, Robey PG, et al. Laminin - a glycoprotein from basement membranes. J Biol Chem 1979; 254: 9933-9937.

12. Kleinman KH, Klebe RJ, Martin GR. Role of collagenous matrices in the adhesion and growth of cells. J Cell Biol 1981;88:473-485.

13. Carpenter MB. Human neuroanatomy, 6th ed., Baltimore: Williams and Wilkins, 1971; 12-25.
14. Schachner M, Schoonmaker G, Hynes RO. Cellular and subcellular localization of LETS protein in the nervous system. Brain Res 1978; 158: 149-155.

15. Shellswell GB, Restall DJ, Duance VC, et al. Identification and differential distribution of collagen types in the central and peripheral nervous systems. FEBS Lett 1979; 106: 305-309.

16. Mauro A, Bertolotto A, Germano I, et al. Collagenase in the immunohistochemical demonstration of laminin, fibronectin and factor VIII/RAg in nervous tissue after fixation. Histochem J 1984; 80: 157-163.

17. Rutka JT, Giblin J, Dougherty DV, et al. An ultrastructural and immunocytochemical analysis of leptomeningeal and meningioma cultures. J Neuropathol Exp Neurol 1986; 45: 285-303.

18. Carlsson J, Nilsson K, Westermark B. Formation and growth of multicellular spheroids of human origin. Int J Cancer 1983; 31 : 523-533.

19. Pahlman S, Ruusala Al, Abrahamsson J. Retinoic acid-induced differentiation of cultured human neuroblastoma cells: a comparison with phorbol ester-induced differentiation. Cell 1984; 14: 135-144.

20. Lotan R. Effects of vitamin A and its analogs (retinoids) on normal and neoplastic cells. Biochim Biophys Acta 1980; 605: 33-91.

21. Lotan R, Lotan D. Stimulation of melanogenesis in a human melanoma cell line by retinoids. Cancer Res 1980; 40: 3345-3350.

22. Strickland S, Smith KK, Marotti KR. Hormonal induction of differentiation in teratocarcinoma stem cells: generation of parietal endoderm by retinoic acid and dibutyryl cAMP. Cell 1980;21: 347-355.

23. Breitman TR, Collins SJ, Keene BR. Terminal differentiation of human promyelocytic leukemic cells in primary culture in response to retinoic acid. Blood 1981; 57: 1000-1004.

24. Kretzschmar HA, DeArmond SJ, Forno LS. Measurement of GFAP in hepatic encephalopathy by ELISA and transblots. J Neuropath Exp Neurol 1985; 44: 459-471.

25. Terranova VP, Rao CN, Kalebic T. Laminin receptor on human breast carcinoma cells. PNAS 1983: 80: 444-450

26. Jones PA, DeClerk YA. Destruction of extracellular matrixes containing glycoproteins, elastin and collagen by metastatic human tumor cells. Cancer Res 1980; 40: 3222-3227.

27. Kao RT, Wong M, Stern R. Elastin degradation by proteases from cultured human breast cancer cells. BBRC 1982; 105: 383-389.

28. Kramer RH, Vogel KG, Nicholson GL. Solubilization and degradation of subendothelial matrix glycoproteins and proteoglycans by metastatic tumor cells. J Biol Chem 1982; 257: 2678-2686.

29. Liotta LA, Tryggvason K, Grabisa S. Metastatic potential correlates with enzymatic degradation of basement membrane collagen. Nature 1980; 284: 67-68.

30. McDonald JK. An overview of protease specificity and catalytic mechanisms: aspects related to nomenclature and classification. Histochem J 1985; 17: 773-785. 